\title{
OCCUPATIONAL HEALTH PROFILES AMONG INFORMAL SECTOR WORKERS IN JEPARA, CENTRAL JAVA
}

\author{
Firdaus Wahyudi, Dodik Pramono, Saekhol Bakri, Bambang Hariyana, \\ Suharto, Arwinda Nugraheni
}

Faculty of Medicine, Universitas Diponegoro

\begin{abstract}
Background: Every industry presents various kinds of safety hazards to its employees. The spectrum of possible occupational safety risks ranges from severe and immediate physical dangers to milder hazards. Occupational accidents directly impact the company's bottom line. An injured employee easily means countless lost man hours and quickly adds up to not only billion rupiahs in company's expenses. This study aimed to describe occupational health profiles among informal sector workers in Jepara, Central Java.

Subjects and Method: This was a cross-sectional study conducted in Plajan village, Jepara, Central Java. A total of 58 informal sector workers were selected for this study. The dependent variable was occupational health. The independent variables were personal protective equipment (PPE), PPE use, occupational disease, work accident, availability of occupational safety and health regulations, smoking prohibition, availability of health workers, availability of the national health insurance (NHI)/BPJS personnel, availability of first aid box, water supply and toilet. The data were collected by questionnaire and described in percent.

Results: Out of 58 informal workers under study, 41 (70.68 \%) worked in the wood craft industry. PPE was available in 25 (43.1\%) locations. PPE use was 2 (3.4\%). Occupational accidents and illness occurred in 52 locations. Occupational illnesses included cough (10.3\%), eye irritation (27.2\%), and hand irritation (10.3\%). Causes of occupational accidents included sharp equipment or machine (89.6\%) and fire (3.4\%). Occupational health and safety regulation was available at 3 (6.8\%) locations. Smoking prohibition, health workers, and the NHI personnel, were absent. First aid boxes were available in $31 \%$ locations. Water supply and toilet were available at all locations.
\end{abstract}

Conclusion: Occupational health and safety remain sub-optimal among informal sector workers, which require close attention from the management.

Keywords: occupational health, safety, accident, informal sector workers.

\section{Correspondence:}

Firdaus Wahyudi. Faculty of Medicine, Universitas Diponegoro, Semarang, Central Java. Email: drfirdauswahyudi@gmail.com. Mobile: 081901023869 